\title{
Lessons From The Current Financial Crisis: Should Credit Rating Agencies Be Re-Structured?
}

\author{
Josh Wolfson, Borough of Manhattan Community College, CUNY, USA \\ Corinne Crawford, Borough of Manhattan Community College, CUNY, USA
}

\begin{abstract}
Credit rating agencies are considered the gatekeepers to the financial markets; however, these agencies have come under increasing attack in the past few years by investors, regulators and the business community. The United States Senate has accused the credit rating agencies of flawed methodology, weak oversight by regulators, conflicts of interest and a total lack of transparency. The Senate review concluded that the problems with the credit rating agencies were responsible for contributing to the housing bubble by awarding AAA ratings to complex, unsafe asset backed securities and other derivatives, thereby magnifying the financial shock when the housing bubble finally burst. In this article, we will explore how the credit rating agencies obtained, and, as many feel, misused their power. In addition, we will outline currently proposed legislative and regulatory solutions.
\end{abstract}

Keywords: Reforming the Credit Rating Agencies

\section{BACKGROUND}

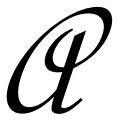

lthough credit rating agencies have been around since 1860, when Henry Varnum Poor first published a statistical analysis of railroads and canals in the United States, they were "officially sanctioned" by the United States government more than a century later. The Securities and Exchange Commission, (SEC) in 1975 introduced the term "Nationally Recognized Statistical Ratings Organizations" (NRSRO's) and incorporated it into rule 15c3-1, which amended the "haircut" requirements for broker-dealers. Since then the SEC has incorporated the term into many of its rules and forms without providing a definition of the term until 2006. The term NRSRO's is used by the SEC in several loosely related contexts; for example, to define eligibility requirements for various registration statements, in rules describing broker-dealer disclosures regarding customer transaction confirmations, and in regulations that provide an exclusion from the definition of "Investment Company" for certain structured finance vehicles issuing highly rated securities.

Ratings issued by NRSRO's affect the types of securities that money market funds may hold and the investment options of pension funds. Regulators now mandate that institutions of all forms pay heed to NRSRO ratings for regulatory compliance. Several rules allow certain investors to purchase only bonds with high NRSRO ratings, while others reduce capital requirements for institutions that purchase these highly rated bonds. It appears obvious that issuers of financial securities cannot access the capital markets unless they have high NRSRO ratings.

Since 1975, the SEC has conferred NRSRO status upon ten agencies. However, three of these agencies have long dominated the marketplace and account for between $95 \%$ and $98 \%$ of all outstanding NRSRO ratings. The lion's share of the market belongs to Moody's Investor Services and Standard \& Poor's Rating Services; Fitch Ratings is a third player whose market share is significantly less than that of its two main rivals.

NRSRO status has profoundly affected credit rating agencies. Since their inception, the credit rating agencies served as information brokers to the capital markets, generating revenue from investors (user-pay). The 
agencies continued to collect fees from the public until 1975 when the SEC introduced the concept of NRSRO's and made an issuer's access to the capital markets impossible without the "blessings" of these rating agencies. The business model, revenue structure and customer base changed dramatically overnight. The rating agencies stopped selling their ratings to investors (user pay) and began selling their ratings to companies whose debt was subject to rating (issuer pay). The new "issuer-pay" model created significant conflicts of interest, namely the challenge for NRSRO's to remain neutral while rating the companies that were generating their revenue. This challenge continues today and many believe it is at the root of the credit rating industry problem.

\section{HUMBLE BEGINNINGS}

In the latter part of the $19^{\text {th }}$ century, railroad construction and development became the largest and most capital-intensive industry in the United States. The railroad industry became the primary focus of many investors, and the financing of its construction and development fostered the growth of the capital markets. Railroad information was at a premium for several reasons; it was costly to gather, difficult to interpret and often inaccessible to the public. The demand for information about this burgeoning industry was enormous and unprecedented. These conditions created a perfect marketing opportunity for those who were able to compile, interpret and disseminate this information. Selling railroad information to throngs of hungry investors proved to be the impetus for the "userpay" revenue model, a business model that proved successful for more than 100 years until the SEC created NRSRO's in 1975.

Henry Varnum Poor was the first to capitalize from such information gathering when he published, "History of Railroads and Canals in the U. S.", in 1860. It was a compilation of statistical data concerning the financial and operating results of the railroads and the railroad industry. In 1868, Henry and his son William published "Poor's Manual of Railroads", which provided information about investing in railroad companies. The manual was updated annually and sold to investors allowing them to chart and track the changes in their railroad company's progress.

Another pioneer to board the "information railroad" and capitalize from selling railroad information was Luther Lee Blake. He established the Standard Statistical Bureau in 1906 and began publishing financial information about the railroad industry. In 1941, Standard Statistics merged with Poor's Publishing Company to form Standard \& Poor's Corporation. Standard \& Poor's was acquired by McGraw-Hill Companies in 1966. Today, Standard \& Poor's is best known for its indices, such as the S\&P 500.

In 1909, John Moody joined the party when he published his first "Manual of Railroad Securities", in which he rated the credit quality of 200 railroad companies. Moody was the first to assign letter grades to the companies and its securities in a declining order of credit quality. "These ratings devised by Moody were not designed to have any specific meanings as might be the case for modern financial analysis. For example, they were not designed to mark categories of expected percentages of expected probability of default. Instead, they were rough compilations of disparate information about bonds that investors found too difficult or costly to assemble on their own" (F. Partnoy, "Rethinking Regulation of Credit Agencies: An Institutional Perspective". April 2009). In 1914 Moody's Investors Services was created, and, within a decade, the company was providing ratings for nearly all government bond markets. By 1970 Moody's had emerged as a full-scale rating agency.

In 1913, John Knowles Fitch established the Fitch Publishing Company that sold statistical and financial analysis to the public in the "Fitch Bond Book" and "Fitch Stock and Bond Manual. In 1924, Fitch introduced the now familiar AAA through D ratings that ultimately became the benchmark by which the financial community based fixed income investment decisions. In the late 1990's, Fitch Publishing Company merged with IBCA of London and acquired market competitors Thomson Bank Watch and Duffs and Phelps Rating Agency to become a full service global rating agency.

\section{GATEKEEPERS TO THE MARKET}

After the crash of 1929, the regulatory landscape changed significantly, and regulators began looking for an expression of "safety" from the rating agencies. They became increasingly reliant on agency ratings and opinions 
concerning the quality of investment portfolio holdings, investment compliance guidelines and expertise in assessing bond issue quality. For example, the Federal Reserve needed assurance that bank portfolios were satisfying capital reserve requirements; individual states needed to determine which bonds were lawful for insurance companies to hold; and the Controller of the Currency needed to make similar decisions for federally chartered banks.

Regulators, in their quest for safety and assurance, inadvertently transformed rating agencies from information brokers to "unofficial gatekeepers" to the financial markets. Regulatory reliance on ratings agencies transformed these informational opinion based databases to required "seals of approval" for those companies needing access to the capital markets. Moreover, access to capital markets became increasingly difficult without the quality assurance from the rating agencies. Thus, the rating agencies expanded their revenue base to include issuing "seals of approval" to issuers. For the next thirty-five years, rating agencies continued to generate revenue by both the selling of information and the rating of securities. By the 1970's the transformation was complete and the primary source of revenue for rating agencies was selling "seals of approval" in the form of credit ratings.

Thus, in the 1970's, the revenue base of the credit rating industry was completely transformed from a userbased system to an issuer based system, where the issuer of a financial instrument pays for its "seal of approval"credit rating. Frank Partnoy, an expert on credit rating agencies who has testified before congress, calls these "seals of approval" a regulatory license- a key that unlocks the door to the financial markets (F. Partnoy, "Committee on Banking, Housing and Urban Affairs". March 7, 2006). The creation of "Nationally Recognized Statistical Rating Organizations" (NRSRO's) by the Securities and Exchange Commission further altered the credit rating agency terrain and "officially" elevated the status of credit rating agencies to that of "financial gatekeepers".

From 1975 to 2006, the SEC used a no-action letter process to recognize credit rating agencies as NRSRO's, eventually identifying seven NRSRO's through this process. This changed with the enactment of the Credit Rating Agency Reform Act of 2006 which defined the term NRSRO and created a voluntary application and registration system for NRSRO recognition. Presently, the SEC has only qualified ten NRSRO's. It has refused to qualify 130 other rating agencies that have applied for NRSRO status. As a consequence, the "big three" rating agencies, Fitch, Moody's and Standard \& Poor's, provide between 95\% and 98\% of securities ratings; the other seven members are minor players.

Due to regulatory requirements, virtually all securities must be rated by an NRSRO. Presently, however, not only do the NRSRO's rate the securities, the agencies also assist the issuers in creating them. This means that the agencies are paid to assist in structuring a security that they will be paid to rate. Both the structuring and the rating of securities are lucrative. Consequently, there are strong incentives for the rating agencies to please the issuers. Furthermore, the rating agencies have been shielded from liability from investor lawsuits due to favorable and protective legislation and case law decisions.

\section{THE CREDIT RATING INDUSTRY'S ROLE IN THE FINANCIAL CRISES OF THE PAST DECADE}

In 2006, the Credit Rating Reform Act was passed, thus ending a century of self-regulation for credit rating agencies. The purpose of the Act was to promote competition and transparency in the industry. Unfortunately, the legislation failed to prevent the financial crisis of 2008. In fact, economic and business leaders cite the credit rating industry for enabling the proliferation of the structured finance vehicles that led to the current financial collapse.

In a February, 2009 speech on the credit rating industry, Securities and Exchange Commissioner, Kathleen L. Casey stated, "For many years, and increasingly after the fall of Enron and WorldCom there have been widespread concerns about the rating industry, including inherent conflicts of interest relating to compensation arrangements, oligopolistic pricing and practices, mediocre ratings quality, failure to issue timely upgrades or downgrades, lack of transparency as to how ratings are determined and a virtual absence of any accountability to investors, markets and regulators"(K. Casey, Commissioner. "SEC Speaks". February 6, 2009). 


\section{PROPOSED REGULATORY REFORM PLANS}

\section{Securities and Exchange Commission}

On September 17, 2009, The Securities and Exchange Committee released adopted and proposed regulations to further strengthen oversight of credit rating agencies. Upon the release, Commissioner Mary Shapiro stated, "These proposals are needed because investors often consider ratings in evaluating whether to purchase or sell a particular security. That reliance did not serve them well over the last several years, and it is incumbent upon us to do all that we can to improve the reliability and integrity of the ratings process and give investors the appropriate context for evaluating whether ratings deserve their trust" (M. Shapiro, Commissioner. "SEC Release 2009-200". September 17, 2009).

Several important rules were adopted on September 17, 2009, including one requiring the credit rating agencies to provide greater information concerning credit ratings histories. Another rule enabled competing credit agencies to provide unsolicited ratings for structured finance products by granting them access to the underlying data for structured products. Additionally, amendments to the commission's rules and forms were adopted to remove certain references to credit ratings by nationally recognized statistical rating organizations.

An important proposed rule was also released, which would require disclosure of information, including what a credit rating covers, any material limitations on the scope of the rating, and whether any preliminary ratings were obtained from other rating agencies.

Perhaps the most important information released was the fact that the commission voted to seek public comment on whether to amend commission rules that would subject NRSROs to liability when a rating is used in connection with a registered offering. This would be accomplished by eliminating a current provision that exempts NRSROs from being treated as experts when their ratings are used that way.

\section{House Financial Services Committee}

On October 28, 2009, The House Financial Services Committee passed "The Accountability and Transparency in Rating Agencies Act”. Upon passage of the Act, Congressman Paul E. Kanjorski, Chairman of the House Financial Services Subcommittee on Capital Markets, Insurance, and Government Sponsored Enterprises, stated, "The Accountability and Transparency Act aims to curb the inappropriate and irresponsible actions of credit rating agencies which greatly contributed to our current economic problems ... as gatekeepers to our markets, credit rating agencies must be held to higher standards" (P. Kanjorski, Congressman. "House Committee on Financial Services": Press Release. October 28, 2009).

The Act would establish a Securities and Exchange Commission Office to regulate NRSRO's (SEC registered credit rating agencies). The Act requires NRSRO's to create a Board of Directors, with at least one third of the board comprised of independent members. The Board would be charged with the development, maintenance and enforcement of policies, procedures and methodologies for determining credit ratings. The Act provides for annual examination of policies, procedures and methodologies of the NRSRO. The purpose of this review is to determine whether the NRSRO has established and documented a system of internal controls, due diligence and implementation of methodologies for determining ratings. The review will also assess compliance to such system and proper disclosures of such adherence.

The Act would require the SEC to issue rules to prohibit or require the management disclosure of conflicts of interest, including specified conflicts relating to compensation of the NRSRO's. The Act requires a 1-year lookback when certain employees begin work for an issuer. The 1-year look-back involves an assessment of the ratings in which the employee was involved to ensure that its procedures were followed and proper ratings were issued. The Act also requires the NRSRO to report to the SEC, and for the SEC to make such reports public. The report must include the names of former employees who are subsequently employed by issuers. 
The Act imposes liability on NRSRO's as it clarifies the right of an individual to sue if the NRSRO fails to conduct an adequate investigation of the rated security. The Act provides that the Securities and Exchange regulations or state regulations do not afford a defense against civil anti-fraud actions.

\section{Senate Banking Committee}

On November 11, 2009, The Senate Banking Committee released draft legislation, "Restoring American Financial Stability Act of 2009. The provisions of this Act are similar to the House Act. This Act would create a new Securities and Exchange Commission "Office of Credit Ratings". In proposing the establishment of the office, the draft legislation stated, "flawed methodology, weak oversight by regulators, conflicts of interest, and a total lack of transparency contributed to a system in which AAA ratings were awarded to complex, unsafe asset-backed securities and other derivatives, adding to the housing bubble and magnifying the financial shock caused when the bubble burst. When investors no longer trusted these ratings during the credit crunch, they pulled back from lending money to municipalities and other borrowers".

The bill requires the SEC to issue rules with respect to procedures and methodologies, including qualitative and quantitative inputs and models, to be used by NRSRO's in rating securities. The procedures and methodologies employed in the ratings must be approved by the NRSRO's Board of Directors. Any changes to the NRSRO's rating methodologies must be applied consistently to all securities and the reason for the change must be publicly disclosed.

The draft legislation requires NRSRO's to maintain, enforce and document an internal control structure to govern implementation of and adherence to policies, procedures and methodologies for determining ratings. The Securities and Exchange Commission would conduct annual examinations of the NRSRO's. The examination would include a review of the internal control procedures and the quantitative and qualitative rating methodologies employed by the NRSRO. Transparency relating to ratings methodology would be enhanced by the bill, as the NRSRO's would be required to disclose information on their performance so that investors could assess the accuracy of the various NRSRO's.

The draft legislation expands the SEC's ability to penalize and fine NRSRO's. The bill would allow the SEC to suspend or revoke registration of an NRSRO with respect to a particular class of securities upon a determination, after notice and opportunity to be heard, that the NRSRO lacks adequate financial or managerial resources to consistently produce ratings with integrity.

Perhaps the most important section of the Act is the provision that eliminates a portion of the NRSRO's protection from liability. Under the legislation a NRSRO could be sued if particular facts give rise to a strong inference that the agency knowingly or recklessly failed to conduct a reasonable investigation of a rated security.

\section{LOOKING TOWARD THE FUTURE}

The Securities and Exchange Commission, congress and the business community acknowledge that there are major problems with the credit rating agencies. Their role in the financial crisis of 2008 is well known. In the past year, the Securities and Exchange Commission and congress have proposed laws and regulations that would assist in restoring confidence to the securities rating industry.

The proposals, as discussed above, all call for more transparency and accountability. The Securities and Exchange Commission would be given additional power to establish rating methodologies and to fine, sanction and rescind NRSRO registration for failure to perform adequate reviews. Perhaps, most importantly, the proposed regulations and legislation call for an end to the protection from liability that the NRSRO's have enjoyed for the past 35 years.

Although these measures are an improvement, do they do not go far enough to ensure a sound rating process? An excellent prescription for reform advanced by many experts in the field, including Frank Partnoy and Professor Curtis Verschoor of DePaul University, is to re- structure the rating industry like the public accounting 
profession. Reforms requiring standard educational certification programs and the licensing of all rating analysts are recommended. Additionally, promulgating "generally accepted rating principles" is proposed. Due to their enormous influence on the capital markets, the securities rating industry should be held to the same professional and ethical standards as the public accounting profession.

There are strong parallels between the public accounting profession and the credit rating industry as both are compensated by the entities they monitor. Furthermore, investors rely on both the public accounting profession and the securities rating agencies to function as financial gatekeepers. Both perform a crucial service to society as their opinions provide a basis for capital allocation.

Over the past century, for the most part, the accounting profession has performed its duties admirably. When deficiencies in accounting practices have been discovered, the profession has enthusiastically embraced the reform measures instituted by the Securities and Exchange Commission and congress. The public accounting profession truly stands as an exemplary profession that may serve as a model for restructuring and reform of the securities credit rating industry.

Finally, we must emphasize that credit ratings issued by NRSRO's and the impact of these ratings on financial markets are quite profound and must not be underestimated. In 1996, twelve years before the current financial crisis, Thomas Friedman of the New York Times described quite well the power and influence these gatekeepers command when he said, "There are two superpowers in the world today in my opinion. There's the United States and there's Moody's Bond Rating Service. The United States can destroy by dropping bombs and Moody's can destroy you by downgrading your bonds. And believe me; it's not clear sometimes who's more powerful” (T Friedman. "News Hour", PBS. February 13, 1996).

\section{AUTHOR INFORMATION}

Josh Wolfson, MBA, CPA is an Accounting Professor and Chair of the Accounting Department at Borough of Manhattan Community College, CUNY, New York, New York. Professor Wolfson began his career as an auditor with Ernst \& Young in 1980. He has been a member of the full time faculty at BMCC for more than 25 years. In addition, Prof. Wolfson taught for Person/Wolinsky, and Convisor/ Duffy CPA Review courses for more than 15 years. Professor Wolfson has a BS in Management from the University of Buffalo, and a MBA from Hofstra University. He is a New York State Certified Public Accountant. A scholarship has been established at Borough of Manhattan Community College to honor Professor Wolfson's teaching excellence. The Josh Wolfson Scholarship is endowed by a former student of Professor Wolfson's. The scholarship is awarded each year to an outstanding accounting student.

Corinne Crawford, MBA, CPA is an Assistant Accounting Professor at Borough of Manhattan Community College, CUNY, New York, New York. She spent 15 years in public accounting, Pricewaterhousecoopers and KPMG, before switching careers to teach full-time. Professor Crawford has been teaching at Borough of Manhattan Community College since 2009. Prior to teaching at BMCC, she was an accounting professor and coordinator of the Accounting Department at Marymount Manhattan College. Professor Crawford has a BS from Fordham University and a MBA Pace University. She is a New York State Certified Public Accountant. Professor Crawford has published several articles in the CPA Journal.

\section{REFERENCES}

1. Securities and Exchange Commission Rule 15c3-1

2. Statement by Lawrence J. White for the "Roundtable to Examine Oversight of Credit Rating Agencies" U.S. Securities and Exchange Commission, April 15, 2009

3. Speech by SEC Staff: Remarks before Catholic Law School Annual Securities Alumni Lunch, Daniel M. Gallagher Co-Acting Director, Division of Trading and Markets U.S. Securities and Trade Commission, November 12, 2009.

4. The Harvard Law School Forum on Corporate Governance and Financial Regulation, "SEC Amends Rules Related to Credit Rating Agencies", December 10, 2009. 
5. Testimony of Frank Partnoy Committee on Housing, Banking and Urban Affairs, March 7, 2006.

6. "Rethinking Regulation of Credit Rating Agencies", White Paper for the Council of Institutional Investors, Professor Frank Partnoy, University of San Diego Law School, April 2009.

7. Securities and Exchange Commission References to Ratings of Nationally Recognized Statistical Organizations, Release number 33-9069, October 5, 2009.

8. Speech by SEC Commissioner, Kathleen L. Casey, In Search of Transparency, Accountability and Competition: The Regulation of Credit Rating Agencies" February 6, 2009.

9. U. S. Securities and Exchange Commission, Chairman Mary L. Shapiro, "Opening Statement before Meeting of the SEC Open Meeting" September 17, 2009.

10. $\quad$ SEC Release 2009-200, September 17, 2009.

11. The House of Representatives, "Accountability and Transparency in Ratings Agencies Act”, September 25, 2009.

12. Senate Committee on Banking Housing and Urban Affairs, "Restoring American Financial Stability Act of 2009".

13. Testimony of Frank Partnoy Hearings before the United States House of Representatives, Subcommittee on Capital Markets, Insurance and Government Sponsored Enterprises, "Legislative Solutions for the Rating Agency Duopoly" June 29, 2005.

14. "Different Actions Needed on Credit Rating Agencies", Professor Curtis Verschoor, DePaul University, June 12, 2009.

15. Interview with Thomas Friedman News Hour, PBS February 13, 1996. 
NOTES 